\title{
Research and Practice on Curriculum System of Water Conservancy Engineering Majors Based on the Oriented Working Process
}

\author{
Cui Zhencai \\ Shandong Water Polytechnic, \\ Rizhao, Shandong, China \\ e-mail:cuizc@sina.com
}

\author{
He Xiaoke, Hu Jinling, Xiaohan \\ Shandong Water Polytechnic, \\ Rizhao, Shandong, China \\ e-mail: hhexk@126.com
}

\begin{abstract}
The thesis analyzed the importance of curriculum system construction of water conservancy engineering based on the oriented working process; It developed the orientation and connotation research in water conservancy engineering with the help of Delphi method, It sorted on the importance of water engineering jobs through comparison of fuzzy binary method, then determined the professional talent location in water conservancy engineering; It transferred water conservancy engineering from "three stages" to "three production process". It determined the typical work task matched for professional posts in production process by practice expert interviews; It determined 16 typical work tasks through school enterprises cooperation and summarized 6 action areas in accordance with the principles of professional talent growth from typical work tasks to action areas, from action areas to learning area processes; It deconstructed and reconstructed the courses based on the working process oriented, It converted 6 action fields to 12 study fields, so as to form a scheme of learning area curriculum; It converted learning objectives and learning content in learning field into didactics and methodology, It constituted a number of learning environment in learning field; which has achieved good results in the practical application in our college.
\end{abstract}

Keywords-oriented working process; water conservancy engineering; curriculum system; application

\section{INTRODUCTION}

Curriculum system refers to a system under the guidance of certain educational value, with various permutations and combinations of the course elements, to enable elements of each course in a dynamic process to target uniformly the achievements of curriculum system [1]. Whether the course system is reasonable or not has direct relation to the cultivation of talents specifications. At present, the majors of water conservancy engineering in higher vocational colleges are still not fully divorced from the traditional "basic course-specialized fundamental course-professional course" three- floor curriculum system. So the talents in the school are not adapted to the professional posts in enterprise. Therefore, it is imminent for majors in water conservancy engineering in higher vocational colleges according to different regions and the characteristics of each school to construct curriculum system based on the oriented work process in accordance with the working process and training target during professional jobs. [2]
With the formally start "national model vocational colleges construction" in China since 2006, according to the talent training target of higher technical ability, the demonstration colleges on the basis of further study and reference to international advanced vocational education concept, and on the basis of the schools with China's national conditions, with the aid of the school-enterprise cooperation platform, innovated development mode and method of course system, constructed the courses based on the oriented working process and used in practice, which laid solid foundation for innovations in higher vocational type characteristic education, reforms in professional talent training mode and teaching quality improvement in higher vocational education [3][4]. But the course development based on oriented working process is a very complicated work, which has extremely strong professional and scientific characters. Nowadays, though, we have more specific curriculum reform direction, can draw lessons from successful examples in the method, due to the nature of the differences between professional--industrial, such as the different regions, the curriculum system researches based on the oriented working process in water conservancy engineering majors of water conservancy colleges and universities have just started, and they didn't form of a unified course standard. The course system practice based on the oriented working process in water conservancy engineering majors is almost blank. Therefore, it is significant to construct curriculum system based on the oriented working process in the water conservancy engineering majors and to use it to guide practical practice.

\section{PROFESSIONAL DIRECTION OF WATER CONSERVANCY ENGINEERING MAJORS AND RESEARCH ANALYSIS OF THE CONNOTATION}

Wherever Times is specified, Times Roman or Times New Roman may be used. If neither is available on your word processor, please use the font closest in appearance to Times. Avoid using bit-mapped fonts if possible. True-Type 1 or Open Type fonts are preferred. Please embed symbol fonts, as well, for math, etc.

According to the current and three-year development of the water conservancy industry and the talent demand for water conservancy in Shandong province, using the questionnaire of Delphi method, we successively researched in Shandong Hydraulic Engineering Corporation, Water Conservancy Engineering Construction \& Supervision Company of Shandong, Rizhao Reservoir Management Office and other 14 units, comprehensively analyzed the 
research results. Professional direction of water conservancy engineering majors and the basic connotation can be summarized as: (1) They are for small and medium-sized water conservancy projects, irrigation and water conservancy projects, water supply project planning and design, construction, supervision and operation management in the town in Shandong province; (2) They are for domestic hub projects in regional water conservancy, integrated river basin management water conservancy projects, cross-regional water transfer projects, the construction of river regulation projects and operation management.

In addition, combined with a survey of graduates who graduated from water conservancy engineering nearly three years, the ratios of the graduates according to the above (1) and (2) are $87.6 \%$ and $12.4 \%$ respectively.

In order to explain the work importance of the graduates who are engaged in water conservancy engineering objectively and scientifically, we utilized the dual relative comparison test of the fuzzy mathematics and the concept of order dual comparison test. Please see table 1about the importance of the sort results on engineering design, construction, and supervision and operation management skills carried out by the actual employers and industry experts.

TABLE I. DUAL COMPARISON SORTING TABLE ON THE IMPORTANCE OF VARIOUS POSTS

\begin{tabular}{|c|c|c|c|c|}
\hline $\boldsymbol{x}_{\boldsymbol{i}}$ & $\begin{array}{c}\mathbf{1} \\
\text { (construction) }\end{array}$ & $\begin{array}{c}\mathbf{2} \\
\text { (supervision) }\end{array}$ & $\begin{array}{c}\mathbf{3} \\
\text { (design) }\end{array}$ & $\begin{array}{c}\mathbf{4} \\
\text { (management) }\end{array}$ \\
\hline $\begin{array}{c}1 \\
\text { (construction) }\end{array}$ & 0.5 & 0.8 & 0.85 & 0.9 \\
\hline $\begin{array}{c}2 \\
\text { (supervision) }\end{array}$ & 0.2 & 0.5 & 0.8 & 0.85 \\
\hline 3 (design) & 0.15 & 0.2 & 0.5 & 0.8 \\
\hline $\begin{array}{c}4 \\
\text { (management) }\end{array}$ & 0.10 & 0.15 & 0.2 & 0.5 \\
\hline
\end{tabular}

According to Table 1 tectonic posts important degree $\mu_{i j}$ matrix:

$$
\mu_{i j}=\left[\begin{array}{cccc}
0.5 & 0.8 & 0.85 & 0.90 \\
0.2 & 0.5 & 0.8 & 0.85 \\
0.15 & 0.2 & 0.5 & 0.8 \\
0.1 & 0.15 & 0.2 & 0.5
\end{array}\right]
$$

$\mu_{i j}$ means $x_{i}$ makes the dual comparison with $x_{j}, x_{i}$ is the important degree of $x_{j} \mu_{i j}$ means $x_{j}$ makes the dual comparison with $x_{i}, x_{j}$ is the important degree of $x_{i}$; $i=1,2,3,4 ; j=1,2,3,4$.

Thus relative important degree matrix of each post is normalized as follows:

$$
\alpha=\left[\begin{array}{cccc}
1 & \frac{0.8}{0.2} & \frac{0.85}{0.15} & \frac{0.9}{0.1} \\
\frac{0.2}{0.8} & 1 & \frac{0.8}{0.2} & \frac{0.85}{0.15} \\
\frac{0.15}{0.85} & \frac{0.2}{0.8} & 1 & \frac{0.8}{0.2} \\
\frac{0.1}{0.9} & \frac{0.15}{0.85} & \frac{0.2}{0.8} & 1
\end{array}\right]=\left[\begin{array}{cccc}
1 & 1 & 1 & 1 \\
0.25 & 1 & 1 & 1 \\
0.18 & 0.25 & 1 & 1 \\
0.11 & 0.18 & 0.25 & 1
\end{array}\right]
$$

Take the minimum value of per line, we get $x_{1}$ (construction), $x_{2}$ (supervision), $x_{3}$ (design), $x_{4}$ (management) the important degree of the $\operatorname{post}(\vec{w}), \vec{w}=(1,0.25$, $0.18, .011)$.so we can get the order of the importance, they are construction $>$ supervision $>$ design $>$ management .

The vocational ability each post needed is divided into general ability, professional ability and comprehensive ability (including social ability, method ability, etc.) (hereinafter referred to the "three abilities"). The further research (to save space, the composition of the ability is not listed) showed: the needs of different post to "three abilities" are consistent, which have the same importance; In the "three abilities ", the requirement of each partial ability in the same post shares the different proportion; The ratios of each respective proportion in the same ability in different posts are different. At the same time, statistical analysis on graduates in water conservancy engineering in the past three years shows the ratios of the posts in construction, supervision, design and management are about 65\%, 16\%, $12 \%, 7 \%$. According to the above analysis, reposition the talents in hydraulic engineering in table 2.

TABLE II. TALENTS POSITIONING IN WATER CONSERVANCY

\begin{tabular}{|c|c|c|c|c|}
\hline $\begin{array}{c}\text { Service } \\
\text { oriented }\end{array}$ & \multicolumn{4}{|c|}{ Water industry } \\
\hline $\begin{array}{l}\text { Employment } \\
\text { Department }\end{array}$ & $\begin{array}{l}\text { Water cons } \\
\text { engineering } \\
\text { township } \\
\text { (studios), } \\
\text { (stations), } \\
\text { managemen }\end{array}$ & $\begin{array}{l}\text { ervancy project } \\
\text { supervision } \\
\text { water conservo } \\
\text { irban or rural } \\
\text { water conserva } \\
\text { t firms, etc }\end{array}$ & $\begin{array}{l}\text { construction } \\
\text { companies, } \\
\text { oncy design } \\
\text { water adm } \\
\text { incy project }\end{array}$ & $\begin{array}{r}\text { companies, } \\
\text { county or } \\
\text { institutes } \\
\text { ninistrations } \\
\text { operation }\end{array}$ \\
\hline $\begin{array}{l}\text { Position and } \\
\text { proportion }\end{array}$ & $\begin{array}{l}\text { Constructio } \\
\mathrm{n} \text { of water } \\
\text { conservancy } \\
\text { project } \\
(65 \%)\end{array}$ & $\begin{array}{l}\text { engineering } \\
\text { supervision(6 } \\
\%)\end{array}$ & $\begin{array}{l}\text { small-scale } \\
\text { water } \\
\text { conservancy } \\
\text { project } \\
\text { design } \\
(12 \%) \\
\end{array}$ & $\begin{array}{l}\text { water } \\
\text { conservancy } \\
\text { project } \\
\text { operation and } \\
\text { management } \\
(7 \%)\end{array}$ \\
\hline Post task & $\begin{array}{l}\text { technical } \\
\text { guidance on } \\
\text { construction } \\
\text {, check and } \\
\text { analysis on } \\
\text { engineering } \\
\text { materials, } \\
\text { the lofting, } \\
\text { organization } \\
\text { and } \\
\text { management } \\
\text { in } \\
\text { construction } \\
\text { site, sort of } \\
\text { engineering } \\
\text { data, project } \\
\text { budget and }\end{array}$ & \begin{tabular}{|l|} 
to perform \\
party A's \\
management \\
and \\
supervision as \\
a \\
representation \\
of engineering \\
construction, to \\
supervise \\
construction \\
site ,to solve \\
and coordinate \\
technical \\
problems, etc
\end{tabular} & $\begin{array}{l}\text { be engaged } \\
\text { in small } \\
\text { design of } \\
\text { hydraulic } \\
\text { engineering } \\
\text { program, } \\
\text { engineering } \\
\text { chart } \\
\text { drawing and } \\
\text { documents } \\
\text { collection } \\
\text { and other } \\
\text { technology } \\
\text { missions in } \\
\text { urban or } \\
\text { rural water } \\
\text { management }\end{array}$ & \begin{tabular}{|l|} 
reservoir \\
engineering, \\
irrigation \\
engineering, \\
all kinds of \\
hydraulic \\
structure \\
security \\
checks, data \\
collection \\
and \\
analysis, \\
maintenance \\
, \\
reinforceme \\
nt tasks in \\
the \\
\end{tabular} \\
\hline
\end{tabular}
ENGINEERING 


\begin{tabular}{|l|l|l|l|}
\hline \multicolumn{1}{|c|}{$\begin{array}{c}\text { Service } \\
\text { oriented }\end{array}$} & \multicolumn{3}{|c|}{ Water industry } \\
\hline $\begin{array}{c}\text { Employment } \\
\text { Department }\end{array}$ & $\begin{array}{l}\text { Water conservancy project construction companies, } \\
\text { engineering supervision companies, county or } \\
\text { township water conservancy design institutes } \\
\text { (studios), urban or rural water administrations } \\
\text { (stations), water conservancy project operation } \\
\text { management firms, etc }\end{array}$ \\
\hline & $\begin{array}{l}\text { formulation } \\
\text { and tender }\end{array}$ & $\begin{array}{l}\text { department } \\
\text { (station) }\end{array}$ & $\begin{array}{l}\text { comprehensi } \\
\text { ve running } \\
\text { management } \\
\text { departments }\end{array}$ \\
\hline Qualification & $\begin{array}{l}\text { The builders, supervision engineers, the surveyors, } \\
\text { material members, librarians, construction cost } \\
\text { members, draftsmen }\end{array}$ \\
\hline $\begin{array}{l}\text { Professional } \\
\text { service } \\
\text { groups }\end{array}$ & $\begin{array}{l}\text { Wrojects, water conservancy and hydropower } \\
\text { engineering managements, urban water conservancies, } \\
\text { water management and relevant majors }\end{array}$ \\
\hline
\end{tabular}

III. PRofessional CURRICULUM SYSTEM CONSTRUCTION BASED ON THE ORIENTED WORKING PROCESS IN WATER CONSERVANCY ENGINEERING MAJORS

\section{A. Research analysis on typical work tasks}

A water conservancy project is mainly divided into planning design, construction and operation management three stages. Each stage has its particular work process, the information to be collected, the mission to be accomplished, the method, the organization forms, the ways to check are different, but each other has close contact, the former stage is the foundation of the latter stage, the latter is the continuing and outspread of the former[5]. Therefore, we can think of the "three stages" in water conservancy project as "three production process". Each production process has some corresponding professional posts, such as construction process in water conservancy projects, which mainly contains construction and construction jobs, construction supervisions, quality testing post positions etc. Every professional post contains relatively independent, systematic, associated typical tasks, which have their own processes of work. Through investigation and analysis, the typical tasks of each position are in the table 3 .

TABLE III. SUMMARY FORM OF TYPICAL TASKS

\begin{tabular}{|c|c|c|c|c|}
\hline Post & $\begin{array}{c}\text { Project } \\
\text { construction }\end{array}$ & $\begin{array}{c}\text { Project } \\
\text { supervision }\end{array}$ & $\begin{array}{c}\text { Minor } \\
\text { project design }\end{array}$ & $\begin{array}{c}\text { Operation\& } \\
\text { management }\end{array}$ \\
\hline tasks & $\begin{array}{l}\text { (1) construction } \\
\text { line (2) } \\
\text { organization } \\
\text { and design } \\
\text { plans, security } \\
\text { plans, quality } \\
\text { and technical } \\
\text { proposals (3) } \\
\text { charter } \\
\text { preparation, } \\
\text { single project } \\
\text { schedule and } \\
\text { human, } \\
\text { material, }\end{array}$ & $\begin{array}{l}\text { (1) quality } \\
\text { supervision } \\
\text { (2) } \\
\text { supervision } \\
\text { of } \\
\text { construction } \\
\text { scheme, } \\
\text { quality and } \\
\text { technology } \\
\text { (3) schedule } \\
\text { of project } \\
\text { and } \\
\text { supervision } \\
\text { of human, }\end{array}$ & $\begin{array}{l}\text { (1) planning } \\
\text { and designs } \\
\text { of farmland } \\
\text { irrigation } \\
\text { and drainage } \\
\text { engineering } \\
\text { (2) designs } \\
\text { of small } \\
\text { brake, dams } \\
\text { and levees, } \\
\text { hole, groove } \\
\text { (3)CAD } \\
\text { engineering }\end{array}$ & $\begin{array}{l}\text { (1) } \\
\text { maintenance } \\
\text { and repair of } \\
\text { all kinds of } \\
\text { dams (2) use } \\
\text { and } \\
\text { management } \\
\text { of the } \\
\text { spillways } \\
\text { (3)the } \\
\text { maintenance } \\
\text { and } \\
\text { management } \\
\text { of the culvert }\end{array}$ \\
\hline
\end{tabular}

\begin{tabular}{|c|c|c|c|c|}
\hline Post & $\begin{array}{c}\text { Project } \\
\text { construction }\end{array}$ & $\begin{array}{c}\text { Project } \\
\text { supervision }\end{array}$ & $\begin{array}{c}\text { Minor } \\
\text { project design }\end{array}$ & $\begin{array}{c}\text { Operation\& } \\
\text { management }\end{array}$ \\
\hline & $\begin{array}{l}\text { machine } \\
\text { utensils and } \\
\text { equipment } \\
\text { planning (4) } \\
\text { quality } \\
\text { evaluation of } \\
\text { the sectional } \\
\text { works }\end{array}$ & $\begin{array}{l}\text { material, } \\
\text { machine } \\
\text { utensils and } \\
\text { equipment } \\
\text { (4) } \\
\text { supervision } \\
\text { of unit } \\
\text { project } \\
\text { quality }\end{array}$ & drawings & $\begin{array}{lr}\text { pips } & \text { and } \\
\text { tunnels } \quad(4) \\
\text { management } \\
\text { of channels } \\
\text { and } \\
\text { channels } \\
\text { buildings (5) } \\
\text { embankment } \\
\text { management } \\
\text { and } \\
\text { emergency } \\
\text { rescue }\end{array}$ \\
\hline
\end{tabular}

$B$. Research and construction in area of action and study

In accordance with the process from typical tasks to the action area, from the action area to the area of study, according to the demand of specialized professional abilities to the professional talents, principles of talents growth and theory- practice integration, through the school-enterprise cooperation, it transferred the 16 typical tasks to 6 action areas. With the guidance of work process, the course deconstruction and reconstruction, it transferred 6 action areas to 12 learning areas, to form the curriculum plan of study field(the study field is abbreviated).

\section{Learning situation carrier and learning situation division}

According to the specific work contents of study field, the thought "from the simple to the complex", the teachers design each teaching project with course experts in the field of learning, so that the students participate in teaching actively, cooperate with each other, and are good at listening and to express their views clearly and accurately in the teaching project. At the same time, they design every learning situation according to the cognitive regularity. "Project" is the carrier of the learning situation, learning situation is the embodiment of "project", the two constitute the whole area of learning.

Then, we clear the ability request, goals and contents, assessment and evaluation, teaching methods and the basic requirements for students and the abilities of the teachers in learning situation, the purpose is to lay the foundation of theory-practice integration teaching.

\section{APPLICATION}

To realize the training of "three abilities", the teachers developed courses in 7 general learning areas (to save space they are abbreviated). There are altogether 520 period hours, the theories are 312 hours and the practice is 208 hours. Expanded learning areas are divided into general learning expanding and professional skill expanding areas (courses of study area are abbreviated). There are three models for students to choose in professional skills expanding areas. The students both can " be required" and" be optional ". Although preparations of the teaching resources should be increased, it is welcomed by the students since it provides more favorable conditions for autonomous learning and personality development. 
In order to use this result, we innovate and practice such a talent training mode "multiple directions, live module, openness, several rounds of school-running". "Multiple directions " mean we set concentration training on water conservancy project construction, water conservancy supervision, and small and medium-sized hydraulic engineering design, water conservancy project management, and other directions before the school-running timely according to the requirements of society, industry, enterprise and students' employment, intent and specialty (the training materials on school-enterprise cooperation are abbreviated); "Live module" means learning area modules, post training modules and the corresponding teaching contents and time arrangement can be regulated flexibly according to the requirements of enterprises and industries; "Openness" means the process of talent training is a whole , comprehensive and a school-enterprise cooperation process ; "Several rounds of school running" means many times of school running combined with the different courses of the professional fields and the sixth term. It is proved that this model promoted the achievement of abilities and goals in each area of study powerfully.

\section{CONCLUSION}

Whether the curriculum system in water conservancy engineering majors based on the oriented working process is scientific, advanced and applicable or not, it depends on the professional direction, informative connotation and work research, and the proper method and scientific statistics results and integration; "typical" general, forward-looking typical work; experience and knowledge of the experts; It also depends on whether the learning areas and learning situations are in accordance with the basic rules of education. Whether it conforms to the growth pattern of vocational talents mainly depends on the course experts' knowledge, ability and education experience.

The courses based on the oriented working process takes working process knowledge as the main content, set up the integrated corresponding relationship between learning and working, solve the problems of the "dual separation between theory and practice, studying and working ". But, the implementation of the curriculum system is vital. Only by building up a scientific talent training mode can it ensure the organization of teaching based on the work process, outstand "task centered" and "situation centered". Therefore, the courses based on the oriented working process and scientific training mode exist side by side, either one should not be suppressed.

\section{REFERENCES}

[1] Fu Wei, Yuan Qiang, Wang Junting, Practice of curriculum system optimization on chemical equipment maintenance technology majors in higher vocational colleges [J]. Vocational and technical education 2011, 32: pp. 9-12.

[2] Han Senhe, Ouyang Dexiang, Course system of the mould majors based on the working process in higher vocational colleges [J].Vocational Education Forum 2012, 2: pp. 48-49.

[3] Zhao Fei, Zeng Xianjun, Hou Jiangli, etc. Research and exploration of the curriculum system based on the working process [J].Education and Vocation 2009, 6: pp. 120-122.

[4] Xia Xiying, Xing Yulin, The basic principles and methods of systematic curriculum development based on the work process. [J].Education and Vocation 2009, 6: pp. 100-102.

[5] He Xiaoke, Cui Zhencai, etc. Higher vocational education technology combining with the teaching mode of the improvidence. [J]. Theory and Practice of Education 2008,6: pp. 94-95. 